\title{
Relationships Among Milk Production, Energy Balance, Plasma Analytes, and Reproduction in Holstein-Friesian Cows
}

\author{
J. Patton, ${ }^{\star} †$ D. A. Kenny,† S. McNamara, ${ }^{\star} \dagger$ J. F. Mee, ${ }^{*}$ F. P. O’Mara,† M. G. Diskin,‡ and J. J. Murphy ${ }^{\star 1}$ \\ ${ }^{*}$ Teagasc Moorepark Dairy Production Research Centre, Fermoy, Co. Cork, Ireland \\ †School of Agriculture, Food Science and Veterinary Medicine, College of Life Sciences, University College Dublin, Ireland \\ $\ddagger$ Animal Reproduction Department, Teagasc Research Centre, Athenry, Co. Galway, Ireland
}

\section{ABSTRACT}

Associations were examined between components and indicators of early lactation energy balance (EB) and measures of fertility in Holstein cows. Milk production, dry matter intake (DMI), body condition score (BCS), and endocrine and metabolite data from 96 cows were analyzed using multivariate logistic regression and survival analysis. Fertility variables investigated were interval to commencement of luteal activity (C-LA), calving to conception interval (CCI), and conception rate to first service (CON1). Mean daily EB, milk protein content, and DMI during the first $28 \mathrm{~d}$ in milk were associated positively with CON1. Cows having poorer BCS $(\leq 2.25)$ at first service had a lower CON1. Positive associations were identified among EB, milk protein content, DMI, and the likelihood of a shorter interval to C-LA. Cows having greater DMI and a more positive EB had an increased likelihood of a shorter CCI, whereas a lower nadir BCS was associated with an increased likelihood of a longer CCI. Milk yield was not associated with any of the fertility variables investigated. A greater plasma concentration of insulin-like growth factor I (IGF-I) during the first 2 wk of lactation was associated with a greater CON1 and an increased likelihood of a shorter interval to C-LA. In conclusion, we identified DMI as the principal component of EB influencing subsequent fertility. Furthermore, results indicate that milk protein content and plasma IGF-I concentration in early lactation may be useful indicators of reproductive efficiency. Key words: energy balance, body condition score, reproduction

\section{INTRODUCTION}

Genetic selection programs based solely on increased milk production have resulted in cows that are genetically predisposed to a greater degree of negative energy balance (NEB) in early lactation. The NEB occurs be-

Received March 22, 2006.

Accepted September 5, 2006.

${ }^{1}$ Corresponding author: john.murphy@teagasc.ie cause increased DMI accounts for only about half of the milk yield response to selection. Additional substrate required to support milk synthesis is provided through enhanced mobilization of adipose reserves and skeletal muscle (Veerkamp, 1998).

An antagonistic relationship exists between genetic merit for milk yield and reproduction, with increasing NEB in early lactation being cited as an underlying causal factor (Jorritsma et al., 2003; Pryce et al., 2004). Failure to establish a successful pregnancy may arise from failure of cows to exhibit estrus, failure to establish an appropriate pattern of ovarian steroidogenesis and follicular growth, or from embryo mortality (Royal et al., 2000). Increasing severity of NEB in early lactation is associated with impaired ovarian function and delayed resumption of estrous cycles (Jolly et al., 1995). Conception rates at first service (CON1) are improved when multiple ovulatory cycles precede insemination (Darwash et al., 1997).

Various metabolites and metabolic hormones, including glucose, NEFA, insulin, and IGF-I, have been implicated as factors affecting ovarian steroidogenesis, follicular dynamics, and in vitro oocyte development (Gong et al., 2002; Leroy et al., 2005). These findings offer potential explanations for latent effects of early postpartum EB on subsequent fertility.

Energy balance is not readily calculable at the farm level and is commonly assessed by monitoring changes in BCS. Increased genetic merit for milk yield is associated with a greater degree of BCS loss in early lactation and less BCS throughout lactation, reflecting a greater degree of NEB (Pryce et al., 2001). The negative relationships reported by Buckley et al. (2003) between BCS in the early lactation period and subsequent reproductive performance support the premise that poor nutritional status compromises reproductive function.

The objective of this study was to identify associations between the components of EB and subsequent fertility performance, as defined by onset of estrous cycles, interval to conception, and conception rate. In addition, we examined the relationships between metabolic, endocrine, and corporal indicators of nutritional status and indices of reproductive efficiency. 
Table 1. Chemical composition (mean \pm SD) of grass and corn silage

\begin{tabular}{|c|c|c|c|c|}
\hline \multirow[b]{2}{*}{ Item } & \multicolumn{2}{|c|}{ Year 1} & \multicolumn{2}{|c|}{ Year 2} \\
\hline & Grass silage & Corn silage & Grass silage & Corn silage \\
\hline $\mathrm{DM}, \mathrm{g} / \mathrm{kg}$ & $171 \pm 29.1$ & $327 \pm 24.5$ & - & $229 \pm 16.1$ \\
\hline $\mathrm{pH}$ & $4.11 \pm 0.36$ & $3.97 \pm 0.14$ & $3.9 \pm 0.13$ & $4.22 \pm 0.26$ \\
\hline $\mathrm{CP}, \mathrm{g} / \mathrm{kg}$ of $\mathrm{DM}$ & $117 \pm 9.7$ & $86 \pm 3.5$ & $136 \pm 4.7$ & $103 \pm 5.1$ \\
\hline $\mathrm{NDF}, \mathrm{g} / \mathrm{kg}$ of $\mathrm{DM}$ & $589 \pm 27.2$ & $465 \pm 24.1$ & $600 \pm 48.1$ & $565 \pm 30.8$ \\
\hline Ash, $\mathrm{g} / \mathrm{kg}$ of DM & $58.3 \pm 8.0$ & $44.5 \pm 6.4$ & $71 \pm 6.0$ & $39 \pm 4.9$ \\
\hline Starch, $\mathrm{g} / \mathrm{kg}$ of DM & - & $168.0 \pm 16.5$ & - & $140.9 \pm 18.5$ \\
\hline $\mathrm{DMD},{ }^{1} \mathrm{~g} / \mathrm{kg}$ of $\mathrm{DM}$ & $697 \pm 40.0$ & $702 \pm 22.2$ & $680 \pm 40$ & $710 \pm 26$ \\
\hline $\mathrm{NE},{ }^{2} \mathrm{UFL} / \mathrm{kg}$ of $\mathrm{DM}$ & 0.79 & 0.90 & 0.78 & 0.75 \\
\hline $\mathrm{NE},{ }^{3} \mathrm{Mcal} / \mathrm{kg}$ of DM & 1.34 & 1.53 & 1.33 & 1.28 \\
\hline
\end{tabular}

${ }^{1} \mathrm{DMD}=\mathrm{DM}$ digestibility.

${ }^{2}$ The net energy (NE) value of grass silage was related to its in vitro DMD concentration (O'Mara et al., 1997). The NE value of corn silage was related to its estimated starch content (Jarrige, 1989). UFL = Unité Fourragère Lait (the $\mathrm{NE}_{\mathrm{L}}$ equivalent of $1 \mathrm{~kg}$ of standard air-dry barley).

${ }^{3}$ Estimated based on $1 \mathrm{UFL}=1.7 \mathrm{Mcal} / \mathrm{kg}$ (Vermorel, 1989).

\section{MATERIALS AND METHODS}

\section{Cows and Management}

Data were collated from 2 experiments of similar design that had been conducted over separate years. Within year, cows had been blocked according to calving date, BCS, and previous milk yield, and assigned randomly to different treatments. The experimental design and details for yr 1 were described previously by $\mathrm{McNa}$ mara (2002). The experimental treatments imposed were once-daily milking during the first 4 wk of lactation and then twice-daily milking during the remaining weeks of lactation (1 $\times ; n=19)$ or 3-times-daily milking during the first $4 \mathrm{wk}$ of lactation and then twice-daily milking during the remaining lactation $(3 \times ; \mathrm{n}=20)$. Cows in both treatments were milked twice daily from d 29 until the end of lactation. A TMR was allocated, consisting of concentrate, corn silage, and grass silage mixed in the ratio 2:1:1. This diet was fed until turnout to pasture at d 42 . There were 39 Holstein-Friesian cows with records for each variable of interest in yr 1 . Tables 1 and 2 show the composition and ingredients of silages and concentrates used in both years of the study.

The experimental design and details for yr 2 were described previously by Patton et al. (2006). The experimental treatments imposed were once-daily milking during the first $4 \mathrm{wk}$ of lactation on a standard diet and twice-daily milking during the remainder of lactation $(\mathbf{1} \times \mathbf{S T} ; \mathrm{n}=21), 3$-times-daily milking during the first 4 wk of lactation on a standard diet and twice-daily milking during the remaining weeks of lactation $(\mathbf{3} \times \mathbf{S T} ; \mathrm{n}=$ 16), or 3-times-daily milking during the first $4 \mathrm{wk}$ of lactation on a high-energy diet and twice-daily milking during the remainder of lactation $(\mathbf{3} \times \mathbf{H E} ; \mathrm{n}=20)$.

The standard diet consisted of ad libitum grass silage and $8 \mathrm{~kg}$ of concentrate. The high-energy diet consisted of ad libitum forage (grass silage and corn silage mixed in a 1:2 ratio on a DM basis) and $12 \mathrm{~kg}$ of concentrate. All cows were milked twice daily from d 29 until the end of lactation. The standard diet was fed to all cows from d 29 until turnout to pasture at d 42 . There were 57 Holstein-Friesian cows with records for each variable of interest in yr 2.

Breeding management was similar during both years. A voluntary waiting period of $65 \mathrm{~d}$ was observed before first service. Detection of estrus was carried out using the HeatWatch (DDx Inc., Denver, CO) system in conjunction with 3 daily visual observations at 0700, 1500, and $1900 \mathrm{~h}$, during and after the voluntary waiting period. HeatWatch transmitters were first applied $14 \mathrm{~d}$ postpartum. An estrus-induction program began on d 65 postpartum (6 cows in yr 1, 3 cows in yr 2 ) in cows not

Table 2. Ingredient and chemical composition (mean \pm SD) of postcalving concentrate supplements

\begin{tabular}{lcc}
\hline Item & Year 1 & Year 2 \\
\hline Ingredient & & \\
Barley, g/kg & 250 & 200 \\
Beet pulp, g/kg & 280 & 220 \\
Soybean meal, g/kg & 200 & 140 \\
Corn gluten feed, g/kg & 250 & 170 \\
Oil (lard), g/kg & 20 & 30 \\
Rapeseed meal & - & 210 \\
Chemical composition $^{1}$ & \\
DM $^{1}$, g/kg & $875 \pm 17$ & $868 \pm 36$ \\
CP, g/kg of DM & $209 \pm 20$ & $202 \pm 69$ \\
Ash, g/kg of DM & $68 \pm 6.3$ & $68 \pm 6$ \\
NDF, g/kg of DM & $214 \pm 21$ & $274 \pm 22$ \\
Starch, g/kg of DM & 189 & 178 \\
NE, ${ }^{1}$ UFL/kg of DM & 0.98 & 1.0 \\
NE ${ }_{\mathrm{L}}{ }^{2}$ Mcal/kg & 1.66 & 1.70 \\
\hline
\end{tabular}

${ }^{1}$ Estimated based on net energy (NE) values for ingredients (INRAtion, version 2.7; Jarrige, 1989). UFL = Unité Fourragère Lait (the $\mathrm{NE}_{\mathrm{L}}$ equivalent of $1 \mathrm{~kg}$ of standard air-dry barley).

${ }^{2}$ Estimated based on $1 \mathrm{UFL}=1.7 \mathrm{Mcal} / \mathrm{kg}$ (Vermorel, 1989). 
previously detected in estrus using a controlled internal drug release (CIDR; InterAg, Hamilton, NZ), which contained $1.94 \mathrm{~g}$ of progesterone, and an injection of $2 \mathrm{mg}$ of estradiol benzoate, $(5 \mathrm{mg} / \mathrm{mL}$; Intervet Ireland Ltd., Cookstown, Dublin, Ireland). The CIDR inserts were removed on $\mathrm{d} 8$ and an injection of $\mathrm{PGF}_{2 \alpha}(2 \mathrm{~mL}$ of Estrumate; BP (Vet) Coopers, Berkhamsted, UK) was administered i.m. Cows received $1 \mathrm{mg}$ of estradiol benzoate 24 $\mathrm{h}$ after CIDR removal. Within year, semen from a single ejaculate was used to inseminate all cows, and the same AI technician performed all inseminations. Duration of the breeding season was $13 \mathrm{wk}$ in both years.

\section{Samples, Measurements, and Laboratory Analysis}

Milk yield was recorded daily at each milking using electronic milk meters (Dairymaster, Causeway, Co. Kerry, Ireland); milking times were 0700, 1500, and 2200 $\mathrm{h}$. The once-daily milking cows were milked at $0700 \mathrm{~h}$. Milk composition (fat, protein, and lactose) was determined twice weekly from successive morning, evening, and night milk samples during the treatment period and once weekly thereafter by automated infrared absorption analysis using a MilkoScan 605 (Foss Electric, Hillerød, Denmark).

Dry matter intake was recorded daily during the first 42 DIM by using Calan door-controlled feeding boxes in yr 1 (McNamara, 2002) and using the Griffith Elder automated feed recording system in yr 2 (Patton et al., 2006). The DM, NDF, crude fiber, and CP of the forage and concentrate samples were analyzed as described by McNamara (2002). Determination of DM digestibility (DMD) was carried out using the procedure described by Tilley and Terry (1963) for yr 1, and by near-infrared spectroscopy using a NIRsystems 6500 spectrophotometer (Perstorp Analytical Incorporated, Silver Spring, MD) for yr 2.

Body weight of cows was recorded once weekly before calving, within $2 \mathrm{~d}$ postcalving, and once weekly thereafter. Preparturient cows were weighed before feeding in the morning and the lactating cows were weighed after the morning milking, before feeding. Body condition score (Lowman et al., 1976) of cows was assessed approximately 2 wk before calving to facilitate blocking, within $4 \mathrm{~d}$ after calving, and then once weekly until the end of the breeding season.

Blood samples were collected twice weekly during the first $4 \mathrm{wk}$ of lactation. Samples were collected in tubes containing lithium heparin as an anticoagulant, placed on ice, centrifuged at $2,000 \times \mathrm{g}$ for $10 \mathrm{~min}$, and stored at $-20^{\circ} \mathrm{C}$ before analysis. Plasma concentrations of glucose, NEFA, and BHBA were determined by enzymatic colorimetry using an ABX Mira autoanalyzer (ABX Mira, Montpellier, Cedex 4, France) and the appropriate enzy- matic kits (glucose: ABX Mira; NEFA: Wako Chemicals GmbH, Neuss, Germany; BHBA: Randox Laboratories Ltd., Crumlin, Co. Antrim, UK). In yr 2 only, samples were analyzed for plasma concentrations of insulin and IGF-I. Insulin in plasma was assayed using a solid-phase RIA (Coat-a-Count; Diagnostic Products Corp., Los Angeles, CA). The inter- and intraassay coefficients of variation were 14.2 and $9.81 \%$, and 9.85 and $3.88 \%$ for samples with mean insulin concentrations of 6.40 and $13.10 \mu \mathrm{IU} / \mathrm{mL}$, respectively. Minimum detectable concentration was $1.61 \pm 0.03 \mu \mathrm{IU} / \mathrm{mL}$. Plasma IGF-I was measured using human OCTEIA IGF-I kits (IDS, Tyne and Wear, UK); releasing reagent was added to dissociate IGF-I from binding proteins. The inter- and intraassay coefficients of variation were 8.7 and $2.1 \%$, respectively, and the sensitivity was $1.9 \mathrm{ng} / \mathrm{mL}$.

Milk samples for progesterone analysis were collected thrice weekly during the morning milking from approximately d 7 after calving until first service. Concentration of progesterone in the milk was measured by enzyme immunoassay from representative unextracted aliquots of whole milk as described by Sauer et al. (1986); sensitivity of the assay was $1 \mathrm{ng} / \mathrm{mL}$. The intraassay CV was $6.9 \%$ and the interassay CV was $13.2 \%$. Conception rate to first service was calculated after pregnancy was diagnosed by using transrectal ultrasonography (Aloka SSD500, 7.5-MHz transducer; Aloka Ltd., Tokyo, Japan) between 30 and $33 \mathrm{~d}$ postinsemination.

\section{Energy Balance}

Energy balance (EB) was estimated as the difference between energy intake and the sum of energy for maintenance and milk production. The French $\mathrm{NE}_{\mathrm{L}}$ system was used, where 1 Unité Fourragère Lait $(\mathbf{U F L})$ is the $\mathrm{NE}_{\mathrm{L}}$ equivalent of $1 \mathrm{~kg}$ of standard air-dry barley. The $\mathrm{NE}_{\mathrm{L}}$ of concentrates fed was determined using the UFL values of ingredients (Jarrige, 1989). The $\mathrm{NE}_{\mathrm{L}}$ value of grass silage was determined from its in vitro DMD concentration (O’Mara et al., 1997).

\section{Data Handling and Statistical Analyses}

There were 96 cows with records available for each variable of interest. No individual cow contributed to the results in both years. The variables investigated are listed in Table 3. Logistic regression analysis (Hosmer and Lemeshow, 1989) was carried out by using SAS software (SAS Institute, 1991) to examine the association between independent variables and CON1, a binary dependent variable $(0,1)$. Data were sorted numerically by each individual continuous independent variable and quartiled or categorized into groups. A reference category was designated for each variable, having an odds 
Table 3. Energy balance (EB), BCS, BW, and plasma analyte variables evaluated in models

\begin{tabular}{|c|c|c|c|}
\hline Model & Variable & Description & Unit \\
\hline \multirow[t]{3}{*}{ EB traits } & Mean EB & Mean daily EB wk 1 to 4 of lactation & $\mathrm{UFL} / \mathrm{d}^{1}$ \\
\hline & EB nadir & Nadir EB, d 1 to 42 of lactation & UFL \\
\hline & Days to nadir EB & Interval from calving until EB nadir & $\mathrm{d}$ \\
\hline EB components & Milk yield & $\begin{array}{l}\text { Mean daily milk yield wk } 1 \text { to } 4 \text { of lactation, at start of breeding } \\
\text { season, cumulative to } 150 \mathrm{~d} \text {, peak yield }\end{array}$ & $\mathrm{kg}$ \\
\hline & Weeks to peak yield & Weeks from calving to peak milk yield & wk \\
\hline & Milk composition & $\begin{array}{l}\text { Milk fat, protein and lactose during wk } 1 \text { to } 4 \text {, at start of breeding } \\
\text { season, cumulative to } 150 \mathrm{~d}\end{array}$ & $\mathrm{~g} / \mathrm{kg}$ \\
\hline & DMI & Mean daily DMI during the first 28 DIM & $\mathrm{kg} / \mathrm{d}$ \\
\hline \multirow[t]{2}{*}{ BCS traits } & BCS & $\mathrm{BCS}$ at calving, $\mathrm{BCS}$ at $\mathrm{AI}$, nadir BCS & 1 to 5 \\
\hline & BCS change & BCS change wk 1 to 4 , from calving to start of breeding season & 1 to 5 \\
\hline \multirow[t]{2}{*}{ BW traits } & BW & $\mathrm{BW}$ at calving, $\mathrm{BW}$ at $\mathrm{AI}$, nadir $\mathrm{BW}$ & $\mathrm{kg}$ \\
\hline & BW change & BW change wk 1 to 4 , from calving to start of breeding season & $\mathrm{kg}$ \\
\hline Metabolites & Plasma glucose, NEFA, BHBA & Mean concentration of metabolites in plasma during wk 1 to 6 & $\mathrm{mmol} / \mathrm{L}$ \\
\hline
\end{tabular}

${ }^{1}$ Estimated based on $1 \mathrm{UFL}=1.7 \mathrm{Mcal} / \mathrm{kg}$ (Vermorel, 1989). UFL = Unité Fourragère Lait (the $\mathrm{NE}_{\mathrm{L}}$ equivalent of $1 \mathrm{~kg}$ of standard airdry barley).

ratio (OR) of 1 . An OR of $>1$ implies an increased likelihood, whereas an OR of $<1$ implies a reduced likelihood. For each category of independent variable, CON1 was compared with CON1 of the reference group for that variable. Each independent variable was first included in a trivariate model containing milking frequency and year as adjustment variables. Variables having $P<0.25$ were retained for inclusion in the final stepwise logistic regression models, which eliminated independent variables with $P>0.05$. The classifiable adjustment variables of year and milking frequency were included in the final models. Multicollinearity was tested by examining the variance inflation factor associated with each independent variable. Univariate analysis was carried out to determine the associations between the adjustment variables and CON1. A coefficient of determination (adjusted $\mathrm{R}^{2}$ ) was used to estimate the proportion of variation explained by each model (Nagelkerke, 1991).

Because of a large correlation between EB and its constituent elements, components of EB were analyzed separately from the traits of the EB profile. Components of EB included milk production, milk composition, and DMI. The EB traits comprised interval to EB nadir, severity of EB nadir, and mean daily EB for the first 28 DIM. A third-order polynomial equation was fitted to the daily EB data of each cow to determine the timing and severity of the EB nadir (Figure 1). Separate multivariate logistic regression models also were constructed to describe CON1 as a function of BCS, BW, and plasma analyte concentrations.
The plasma analyte variables created were mean concentrations for the first 2 wk of lactation, and mean concentrations for wk 1 to 4 of lactation. Plasma insulin and IGF-I concentrations were measured in yr 2 only. Consequently, analyses of the association between insulin and IGF-I concentrations and CON1 were carried out with the analytes modeled as continuous variables adjusted for within-year treatment.

Survival analysis was carried out using the Cox proportional hazard model in SAS (SAS Institute, 1991) to investigate the relationship between independent variables and intervals from calving to commencement of

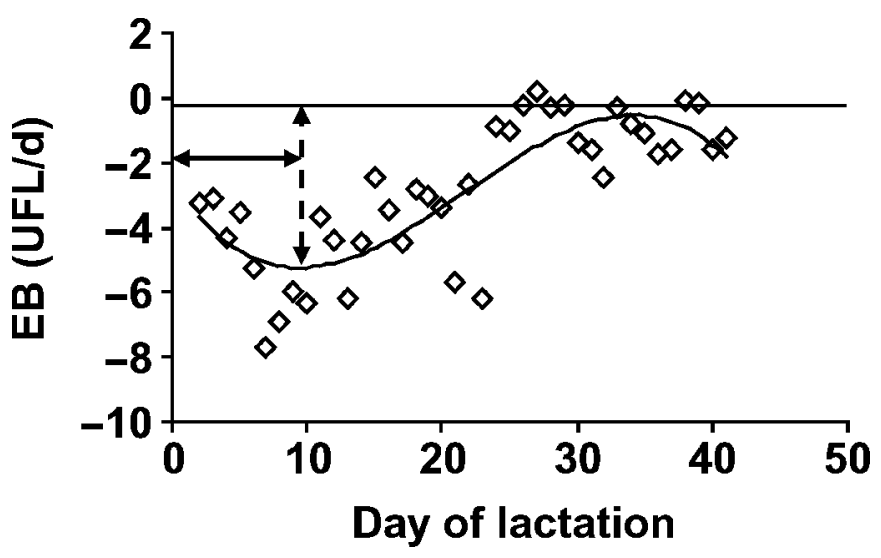

Figure 1. Definition and calculation of energy balance (EB) traits. Interval from calving to EB nadir $(\leftrightarrow)$; UFL = Unité Fourragère Lait (the $\mathrm{NE}_{\mathrm{L}}$ equivalent of $1 \mathrm{~kg}$ of standard air-dry barley). 
luteal activity (C-LA) and calving to conception (CCI). Interval to C-LA was defined as the interval from parturition until the first day of the occurrence of 2 or more consecutive milk samples having progesterone $>3 \mathrm{ng} / \mathrm{mL}$ (Royal et al., 2000). If a cow did not have 2 or more successive samples in which milk progesterone exceeded $3 \mathrm{ng} / \mathrm{mL}$ before $\mathrm{d} 65$, she was considered censored. The CCI was defined as the interval from calving until the date of the insemination resulting in a positive pregnancy diagnosis $30 \mathrm{~d}$ subsequent to that insemination. If a cow was not confirmed as pregnant to any insemination occurring during the breeding season, she was considered censored. The proportional hazards assumption for each independent variable was tested by including a time-covariate interaction term (Allison, 1995). A hazard ratio $(\mathbf{H R})$ of $>1$ indicates that a unit increase in the value of the independent variable is associated with an increased likelihood of earlier occurrence of the event of interest.

Similar to the logistic regression analysis, each explanatory variable was first tested in a trivariate model including year and milking frequency as adjustment variables. Variables having $P<0.25$ were retained for inclusion in stepwise models, to explain differences in time to ovulation and conception as functions of $\mathrm{EB}$ traits, EB components, BW, BCS, and plasma analytes. The stepwise model eliminated variables having $P>$ 0.05 .

\section{RESULTS}

The descriptive statistics for milk production, BW, BCS, DMI, and EB are presented in Table 4. Mean interval to C-LA was $31 \pm 15 \mathrm{~d}$ (mean $\pm \mathrm{SD}$ ) and the CCI was $99 \pm 34 \mathrm{~d}$, respectively, whereas overall CON1 was $61 \%$. Nine cows did not ovulate before d 65 and were censored, whereas 13 were censored for having failed to conceive before the end of the breeding season.

Results of the univariate analysis of adjustment and fertility variables are outlined in Table 5 . Cows milked once daily were more likely $(\mathrm{HR}=0.76 ; P=0.01)$ to resume cyclicity earlier compared with cows milked 3 times daily. Once-daily milking was not associated with an increased likelihood of shorter CCI (OR $=0.97 ; P=$ $0.83)$. Cows in yr 2 tended to have an increased likelihood of shorter CCI $(\mathrm{OR}=0.67 ; P=0.09)$.

\section{EB, BCS, Plasma Analytes, and CON1}

Relationships between milk production, feed intake, $\mathrm{EB}$ variables, and CON1 are included in Table 6. Level of milk production was not associated with CON1, either during wk 1 to 4 of lactation or at time of first service. Similarly, peak milk yield was not associated with CON1.
Milk protein concentration during wk 1 to 4 of lactation was associated positively $(P<0.01)$ with CON1. Cows in the 2 lowest milk protein content quartiles had a lesser likelihood of CON1 $(\mathrm{OR}=0.08, P<0.01$; and $\mathrm{OR}=0.17, P=0.02$; respectively) compared with the reference $(>35.5 \mathrm{~g} / \mathrm{kg})$ category. A positive relationship was detected $(P=0.01)$ between mean DMI for the first 4 wk of lactation and subsequent CON1. Cows in the lowest DMI quartile $(<12.5 \mathrm{~kg} / \mathrm{d})$ had a lesser likelihood of CON1 (OR $=0.08, P<0.01)$ compared with cows in the highest DMI category $(>16.8 \mathrm{~kg} / \mathrm{d})$. Adjusted $R^{2}$ of the EB components model was 0.33 .

Of the EB traits measured, mean daily EB during wk 1 to 4 of lactation was associated $(P=0.03)$ with likelihood of CON1. Likelihood of CON1 decreased $(P<0.01)$ with increasing severity of NEB; cows in the most negative EB quartile $(<-5.35 \mathrm{UFL} / \mathrm{d})$ had a reduced likelihood of CON1 (OR $=0.10)$ compared with the reference category ( $>-1.95 \mathrm{UFL} / \mathrm{d})$. Adjusted $\mathrm{R}^{2}$ of the EB traits model was 0.14 .

None of the BW variables measured (weight at AI, nadir weight, and weight loss from calving to $\mathrm{AI}$ ) was associated with likelihood of CON1. Of the BCS variables examined, BCS at the time of first insemination was associated $(P=0.02)$ with CON1. Cows with a BCS of 2.25 or less at the time of first insemination had a lesser $(\mathrm{OR}=0.10, P<0.01)$ likelihood of CON1 when compared with cows in the reference category (BCS $\geq 3.25$ ). Adjusted $\mathrm{R}^{2}$ of the BCS model was 0.17.

No significant relationships were identified between any of the plasma metabolites measured and CON1. Plasma insulin concentration (measured in yr 2) was not associated with CON1. Mean plasma IGF-I concentration (measured in yr 2) during the first 2 wk of lactation was shown to be associated positively ( $\mathrm{OR}=1.15, P=$ 0.02 ) with likelihood of CON1 (Table 7). Adjusted $R^{2}$ of the IGF-I model was 0.17 .

\section{EB, BCS, Plasma Analytes, and C-LA}

Relationships between resumption of first luteal function (C-LA) and milk production, DMI, and EB are outlined in Table 8. Of the EB components measured, greater milk protein concentration $(\mathrm{HR}=2.45, P=0.04)$ and DMI $(\mathrm{OR}=1.14, P<0.01)$ in early lactation were associated with increased likelihood of earlier C-LA. A positive association $(\mathrm{OR}=1.12, P=0.04)$ was also observed between early lactation EB and the likelihood of earlier C-LA.

Plasma IGF-I concentration was shown to be associated with C-LA (Table 7). Cows having greater mean plasma IGF-I concentration during the first $2 \mathrm{wk}$ of lactation had an increased $(\mathrm{OR}=1.05, P=0.01)$ likelihood of earlier C-LA. In contrast, C-LA was not associated 
Table 4. Means (SEM in parentheses) of milk production, DMI, energy balance (EB), BCS, and BW, and plasma analytes for experimental groups ${ }^{1}$ used in the study

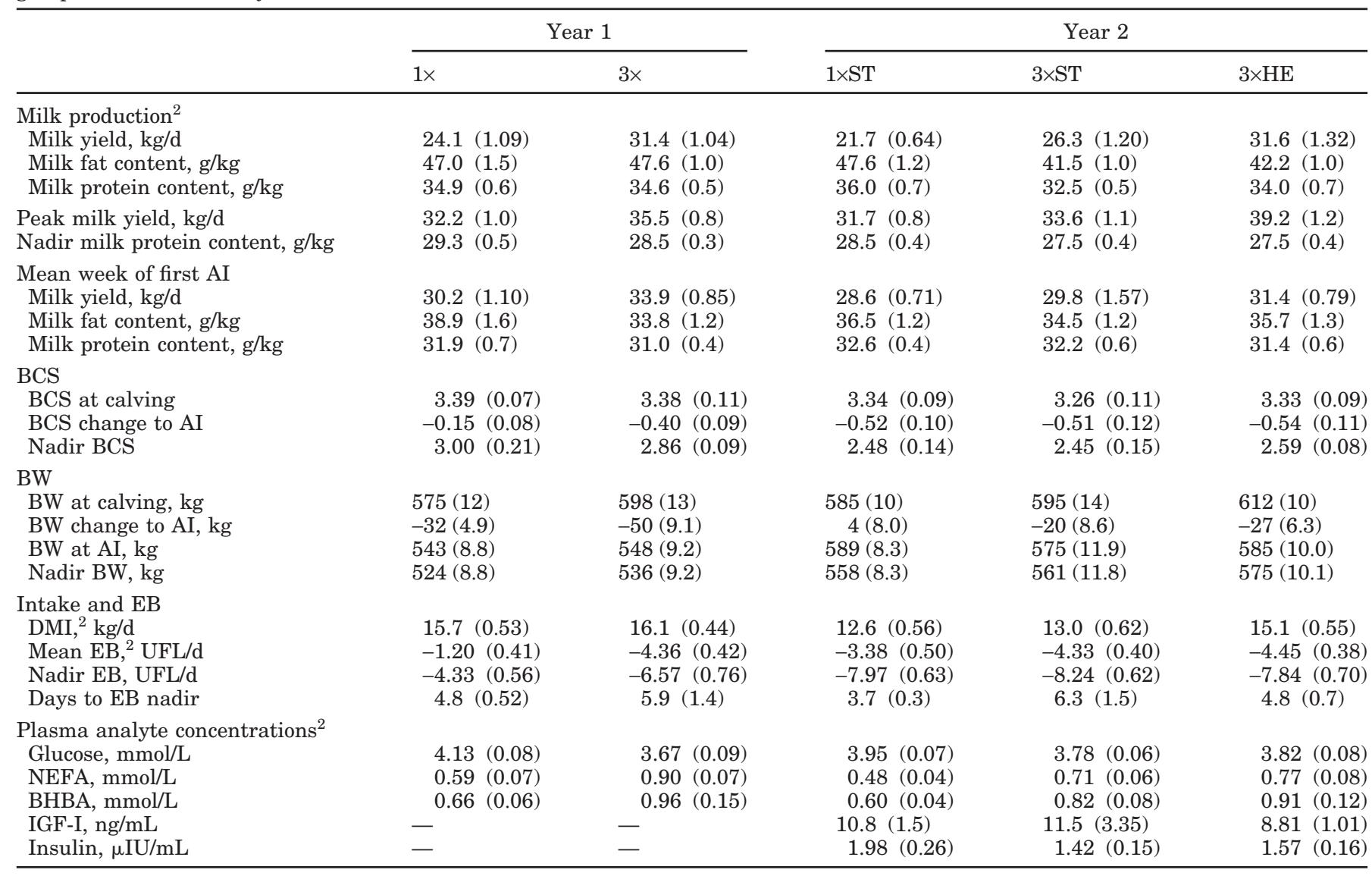

${ }^{1} 1 \times=$ Once-daily milking in yr $1 ; 3 \times=3$-times-daily milking in yr $1 ; 1 \times \mathrm{ST}=$ once-daily milking on standard diet in yr $2 ; 3 \times \mathrm{ST}=3$-timesdaily milking on standard diet in yr $2 ; 3 \times \mathrm{HE}=3$-times-daily on high-energy diet in yr 2 .

${ }^{2}$ Values presented are means for wk 1 to 4 of lactation.

with plasma insulin concentration or plasma concentration of any of the metabolites measured.

\section{EB, BCS, Plasma Analytes, and CCI}

Associations between CCI and milk production, EB, DMI, and BCS are summarized in Table 9. A more posi- tive EB in wk 1 to 4 of lactation was associated with an increased $(\mathrm{OR}=1.13, P=0.02)$ likelihood of a shorter CCI, whereas a greater DMI at this time also increased (OR 1.12, $P=0.03$ ) the likelihood of shorter CCI. None of the milk yield or milk composition variables measured was associated with CCI. There were no relationships observed between CCI and any of the BW variables mea-

Table 5. Univariate associations between adjustment variables and fertility variables

\begin{tabular}{|c|c|c|c|c|}
\hline Dependent variable & $\begin{array}{l}\text { Adjustment } \\
\text { variable }\end{array}$ & $\begin{array}{l}\text { Odds } \\
\text { ratio }\end{array}$ & $95 \% \mathrm{CI}^{1}$ & $P$-value \\
\hline \multirow[t]{3}{*}{ Conception rate to first service $(n=96)$} & Milking frequency & 0.7 & $0.30-1.61$ & 0.40 \\
\hline & Year & 1.53 & $0.65-3.62$ & 0.33 \\
\hline & & $\begin{array}{l}\text { Hazard } \\
\text { ratio }\end{array}$ & $95 \% \mathrm{CI}$ & $P$-value \\
\hline \multirow[t]{2}{*}{ Interval to commencement of luteal activity $(\mathrm{n}=96)$} & Milking frequency & 0.76 & $0.61-0.94$ & 0.01 \\
\hline & Year & 1.29 & $0.83-2.02$ & 0.25 \\
\hline \multirow[t]{2}{*}{ Calving to conception interval } & Milking frequency & 0.97 & $0.78-1.22$ & 0.83 \\
\hline & Year & 0.67 & $0.43-1.05$ & 0.09 \\
\hline
\end{tabular}

${ }^{1} \mathrm{CI}=$ Confidence interval. 
Table 6. Relationship between milk production, energy balance (EB), DMI, BCS, and conception rate to first service

\begin{tabular}{|c|c|c|c|}
\hline Model & $\begin{array}{l}\text { Odds } \\
\text { ratio }\end{array}$ & $95 \% \mathrm{CI}^{1}$ & $P$-value \\
\hline \multicolumn{4}{|c|}{ Model relating EB components to conception rate at first service $(n=96)$} \\
\hline$>35.7$ & 1 & & \\
\hline 33.6 to 35.7 & 0.69 & $0.17-2.89$ & 0.61 \\
\hline 32.3 to 33.5 & 0.08 & $0.02-0.43$ & $<0.01$ \\
\hline$<32.3$ & 0.17 & $0.04-0.79$ & 0.02 \\
\hline \multicolumn{4}{|l|}{ DMI, kg/d } \\
\hline$>16.8$ & 1 & & \\
\hline 14.9 to 16.8 & 0.28 & $0.06-1.39$ & 0.12 \\
\hline 12.5 to 14.8 & 0.07 & $0.01-0.40$ & $<0.01$ \\
\hline$<12.5$ & 0.08 & $0.02-0.47$ & $<0.01$ \\
\hline \multicolumn{4}{|c|}{ Model relating EB traits to conception rate at first service $(\mathrm{n}=96)$} \\
\hline \multicolumn{4}{|c|}{ Mean EB during first $28 \mathrm{DIM}, \mathrm{UFL} / \mathrm{d}^{2}$} \\
\hline$>-1.95$ & 1 & & \\
\hline-1.95 to -3.44 & 0.34 & $0.08-1.42$ & 0.14 \\
\hline-3.45 to -5.35 & 0.19 & $0.40-0.93$ & 0.04 \\
\hline$<-5.35$ & 0.10 & $0.02-0.50$ & $<0.01$ \\
\hline \multicolumn{4}{|c|}{ Model relating BCS to conception rate at first service $(\mathrm{n}=96)$} \\
\hline \multicolumn{4}{|c|}{$\mathrm{BCS}$ at $\mathrm{AI}$} \\
\hline$\geq 3.25$ & 1 & & \\
\hline 3.0 & 0.35 & $0.09-1.36$ & 0.13 \\
\hline 2.5 to 2.75 & 0.49 & $0.12-2.04$ & 0.33 \\
\hline$\leq 2.25$ & 0.10 & $0.02-0.48$ & $<0.01$ \\
\hline
\end{tabular}

${ }^{1} \mathrm{CI}=$ Confidence interval.

${ }^{2} \mathrm{UFL}=$ Unité Fourragère Lait (the $\mathrm{NE}_{\mathrm{L}}$ equivalent of $1 \mathrm{~kg}$ of standard air-dry barley).

sured. Of the BCS variables investigated, nadir BCS was shown to be associated positively $(\mathrm{OR}=1.06, P=$ 0.03 ) with CCI. This indicates that cows reaching a lower nadir BCS had an increased likelihood of a prolonged CCI.

\section{DISCUSSION}

Negative associations between early lactation energy status and subsequent fertility have been reported in numerous studies (Butler, 2003). The objective of the current study was to identify the principal components, characteristics, and indicators of EB affecting reproductive outcomes. Multivariate analysis was used to allow for simultaneous evaluation of a range of correlated and interacting $\mathrm{EB}$ variables.

As previously outlined, variables describing the EB profile were analyzed separately from variables used in EB calculations to avoid collinearity. Mean daily EB during the first 28 DIM was the primary EB trait associated with fertility, being positively associated with likelihood of earlier ovulation. This is consistent with Butler and Smith (1989), who reported that resumption of ovarian cyclicity is delayed by an increased magnitude of energy deficit during the first $3 \mathrm{wk}$ of lactation. The interval to EB nadir has also been implicated in the timing of first ovulation, with dominant follicles emerging after the nadir having enhanced estradiol secretion

Table 7. Relationship between plasma IGF-I concentration during the first 2 wk of lactation and reproductive traits

\begin{tabular}{llll}
\hline Model & $\begin{array}{l}\text { Odds } \\
\text { ratio }\end{array}$ & $95 \% \mathrm{CI}^{1}$ & $P$-value \\
\hline $\begin{array}{l}\text { Plasma IGF d 1-14 vs. } \\
\text { conception rate at first service }(\mathrm{n}=59)\end{array}$ & $\begin{array}{l}1.15 \\
\text { Hazard } \\
\text { ratio }\end{array}$ & $1.02-1.29$ & 0.02 \\
\cline { 2 - 4 } $\begin{array}{l}\text { Plasma IGF-I d 1-14 vs. } \\
\text { interval to commencement of luteal activity }\end{array}$ & 1.05 & $95 \% \mathrm{CI}$ & \\
\hline${ }^{1} \mathrm{CI}=$ Confidence interval. & & & 0.01 \\
\hline
\end{tabular}


Table 8. Relationship between milk production, intake, energy balance (EB), and commencement of luteal activity

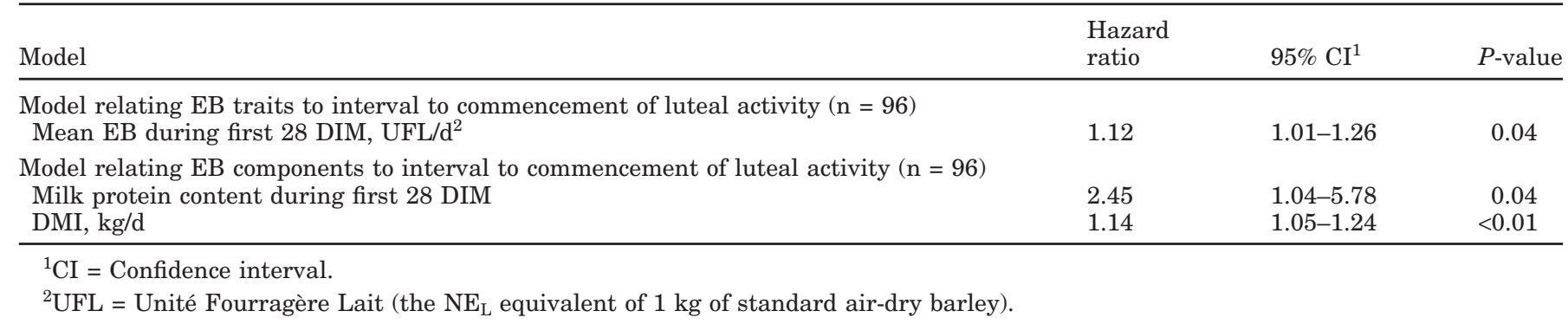

and a greater likelihood of ovulatory success (Beam and Butler, 1997). Timing of the EB nadir was not associated with onset of luteal function in the current study. There was little variation in the timing of the EB nadir; the majority $(>80 \%)$ of cows experienced their nadir EB during the first week of lactation. This was somewhat earlier than reported elsewhere (Butler 2003).

Mean daily EB during the first 28 DIM was positively related to conception rate at first insemination in this study, indicating that early postpartum nutritional status may exert carryover effects on fertility during the breeding season. Britt (1994) hypothesized that follicles exposed to adverse conditions such as severe NEB during their initial stages of growth would have impaired development, resulting in the production of poor-quality oocytes and dysfunctional corpora lutea. The supposition that early postpartum EB affects fertility is supported by the results of Gümen et al. (2005), who showed that elimination of the dry period resulted in a more positive postpartum EB, a shorter interval to first ovulation, and a greater subsequent first-service conception rate. The potential influence of early postpartum EB on subsequent reproductive function is further evidenced by the findings of Villa-Godoy et al. (1988), who reported that EB in early lactation was positively correlated with progesterone secretion during the second and third estrous cycles.
Absence of an association between milk production and reproductive function was a notable feature of the current study. There is convincing evidence that genetic selection for increased milk yield adversely affects fertility (Pryce et al., 2004). An important distinction between genotypic and phenotypic milk yield is required, however, because genetic capacity for milk yield may affect reproductive outcomes differently than phenotypic milk production. For example, Snijders et al. (1999) demonstrated that oocytes recovered from cows of high genetic merit formed fewer blastocysts and had lower rates of blastocyst formation, but level of milk production had no effect on oocyte quality. Buckley et al. (2003) reported that reproductive performance declined as genetic merit for milk yield increased. The same study demonstrated that reproductive performance was associated positively with milk yield, after adjustment for genetic merit. Furthermore, in a large-scale field study of commercial dairy herds, Morton (2001) found no relationship between reproductive performance and milk yield, but that cows with greater milk protein content in early lactation had substantially better reproductive performance. Similarly, positive relationships were identified between conception rate, onset of luteal function, and milk protein content in the current study. Milk protein concentration is recognized as an important indicator of $\mathrm{EB}$, cows with

Table 9. Relationship between milk production, DMI, energy balance (EB), BCS, and calving to conception interval

\begin{tabular}{llll}
\hline Model & $\begin{array}{l}\text { Hazard } \\
\text { ratio }^{1}\end{array}$ & $95 \% \mathrm{CI}^{2}$ & $P$-value \\
\hline $\begin{array}{l}\text { Model relating EB components to calving to conception interval } \\
\quad \text { DMI during first 28 DIM, kg/d }\end{array}$ & 1.12 & $1.01-1.23$ & 0.03 \\
$\begin{array}{l}\text { Model relating EB traits to CCI } \\
\quad \text { Mean EB during first 28 DIM, UFL/d }\end{array}$ & 1.13 & $1.02-1.27$ & 0.02 \\
$\begin{array}{l}\text { Model relating BCS variables to CCI } \\
\text { Nadir BCS }\end{array}$ & 1.06 & $1.02-1.12$ & 0.03 \\
\hline
\end{tabular}

${ }^{1}$ Hazard ratio for proportional hazards regression.

${ }^{2} \mathrm{CI}=$ Confidence interval.

${ }^{3} \mathrm{UFL}=$ Unité Fourragère Lait (the $\mathrm{NE}_{\mathrm{L}}$ equivalent of $1 \mathrm{~kg}$ of standard air-dry barley). 
a lesser milk protein concentration having a more prolonged and severe energy deficit (Fulkerson et al., 2001).

Increased DMI during early lactation was associated with earlier resumption of cyclicity, greater conception rate to first insemination, and a shorter calving to conception interval. Variation in EB was explained primarily by differences in energy intake rather than milk yield (Villa-Godoy et al., 1988). This may explain why the relationships between DMI and reproductive function were similar to those observed for EB, whereas milk yield was not associated with fertility.

Results of the present study demonstrate that DMI is the primary component of EB affecting reproduction. Increasing dietary energy intake is, however, restricted by the requirement for inclusion of dietary fiber to maintain rumen function. In addition, considerable variation exists in the capacity for voluntary feed intake among cows, so feed allowance is not predictive of feed ingested (Villa-Godoy et al., 1988). Therefore, efficacy of increasing dietary allowance to improve nutritional status is likely to be limited by the inherent voluntary capacity of individual cows.

In the present study, cows having lower BCS $(\leq 2.25)$ at the time of insemination had a reduced likelihood of conception, whereas cows with a lower BCS nadir had a greater likelihood of a longer interval to conception, reflecting the relationships described between EB and fertility. Excessive loss of BCS in early lactation and poor BCS at the start of the breeding season have proven to be predictive of poor fertility performance in previous studies (Domecq et al., 1997; Buckley et al., 2003).

Glucose is recognized as a major source of energy for the ovary (Rabiee et al., 1999), whereas increased NEFA concentration has been shown to have negative effects on in vitro oocyte maturation and fertilization (Leroy et al., 2005). Plasma concentrations of glucose, NEFA, and BHBA during early lactation were found to have no association with resumption of cyclicity or conception rate. Although associations between these metabolites and early lactation EB are well established and reflect enhanced mobilization of body reserves and partitioning of nutrients toward milk production, precision of estimation of EB for individual cows from plasma metabolite profiles is poor (Reist et al., 2002). Thus, it seems that measuring systemic concentrations of plasma metabolites may not be sufficiently precise for gauging EB effects on reproductive function.

Insulin and IGF-I have numerous direct effects on ovarian cells, including stimulation of granulosa cell mitogenesis, progesterone secretion from luteal cells, and thecal cell androgen production (Spicer et al., 1993). Plasma IGF-I concentration is directly related to energy status, and IGF-I has thus been cited as a potential hormonal mediator of nutritional control of fertility
(Zulu et al., 2002). In the present study, increased plasma IGF-I in the first $2 \mathrm{wk}$ of lactation was associated with an increased likelihood of earlier ovulation. Plasma IGF-I concentration was previously shown to be greater during the first 2 wk postpartum in cows with an ovulatory vs. nonovulatory first dominant follicle (Beam and Butler, 1997). The same study noted greater plasma insulin concentrations during the first postpartum week in cows with an ovulatory first dominant follicle, although not in subsequent weeks. Plasma insulin concentration in early lactation was not associated with any measure of reproductive performance in the current study.

Although results should be interpreted cautiously owing to limited experimental numbers, it is noteworthy that plasma IGF-I concentration during the early postpartum period was associated with conception rate to first service. This is in agreement with the relationships noted among EB, DMI, and conception rate, and further implicates an effect of early lactation metabolic status on subsequent reproductive performance.

\section{CONCLUSIONS}

Energy balance during early lactation was associated positively with conception rate to first insemination. In addition, a more positive EB was associated with a greater likelihood of earlier resumption of cyclicity and earlier conception. No relationships were identified between level of milk production, either during early lactation or at the time of first insemination, and reproductive outcomes. Relationships between DMI and measures of fertility were, however, similar to EB, indicating that DMI is the principal component mediating EB effects on reproductive function. Assessing milk protein content and plasma IGF-I concentration during the early postpartum period may be useful as indicators of subsequent fertility.

\section{ACKNOWLEDGMENTS}

The authors thank J. P. Murphy, N. Byrne, J. Kenneally, and the Moorepark farm staff for management and care of the animals. The technical assistance of $\mathrm{T}$. Condon, J. Dwyer, N. Galvin, N. Hynes, J. Haugh, and S. Llewellyn is also appreciated. Wellcome Trust and National Development Plan funding is gratefully acknowledged.

\section{REFERENCES}

Allison, P. A. 1995. Survival analysis using the SAS system: A practical guide. SAS Institute, Inc., Cary, NC.

Beam, S. W., and W. R. Butler. 1997. Energy balance and ovarian follicle development prior to the first ovulation postpartum in dairy cows receiving three levels of dietary fat. Biol. Reprod. 56:133-142. 
Britt, J. H. 1994. Follicular development and fertility: Potential impacts of negative energy balance. Pages 103-112 in the Proc. Natl. Reprod. Symp., Pittsburgh, PA. American Association of Bovine Practitioners, Auburn, AL.

Buckley, F. P., K. O'Sullivan, J. F. Mee, R. D. Evans, and P. Dillon. 2003. Relationships among milk yield, body condition, cow weight, and reproduction in spring-calved Holstein-Friesians. J. Dairy Sci. 86:2308-2319.

Butler, W. R. 2003. Energy balance relationships with follicular development, ovulation and fertility in postpartum dairy cows. Livest. Prod. Sci. 83:211-218.

Butler, W. R., and R. D. Smith. 1989. Interrelationships between energy balance and postpartum reproductive function in dairy cattle. J. Dairy Sci. 72:767-783.

Darwash, A. O., G. E. Lamming, and A. J. Woolliams. 1997. The phenotypic association between the interval to postpartum ovulation and traditional measures of fertility in dairy cattle. Anim. Sci. 65:9-16.

Domecq, J. J., A. L. Skidmore, J. W. Lloyd, and J. B. Kaneene. 1997. Relationship between body condition scores and conception at first artificial insemination in a large dairy herd of high yielding Holstein cows. J. Dairy Sci. 80:113-120.

Fulkerson, W. J., J. Wilkins, R. C. Dobos, G. M. Hough, M. E. Goddard, and T. Davidson. 2001. Reproductive performance in HolsteinFriesian cows in relation to genetic merit and level of feeding when grazing pasture. Anim. Sci. 73:397-406.

Gong, J. G., W. J. Lee, P. C. Garnsworthy, and R. Webb. 2002. Effect of dietary-induced increases in circulating insulin concentrations during the early postpartum period on reproductive function in dairy cows. Reproduction 123:419-427.

Gümen, A., R. R. Rastani, R. R. Grummer, and M. C. Wiltbank. 2005. Reduced dry periods and varying prepartum diets alter postpartum ovulation and reproductive measures. J. Dairy Sci. 88:2401-2411.

Hosmer, D. W., and S. Lemeshow. 1989. Applied logistic regression. Wiley, New York, NY.

Jarrige, J., ed. 1989. INRAtion. V2.7. Microsoft computer program of ration formulation for ruminant livestock. 1. Dairy cows (J. B. Coulon and P. Faverdin). 2. Sheep (F. Bocquier and A. Brelurut). 3. Growing and finishing cattle (D. Micol, J. Robelin, and J. Agabriel). 4. Suckler cows (J. Agabriel). 5. Goats (D. Sauvant). J. Agabriel, P. Champciaux, and C. Espinasse, ed. CNERTA, Dijon, France.

Jolly, P. D., S. McDougall, L. A. Fitzpatrick, K. L. Macmillan, and K. Entwhistle. 1995. Physiological effects of undernutrition on postpartum anestrus in cows. J. Reprod. Fertil. Suppl. 49:477-492.

Jorritsma, R., T. Wensing, T. Kruip, P. Vos, and J. Noordhuizen. 2003. Metabolic changes in early lactation and impaired reproductive performance in dairy cows. Vet. Res. 34:11-26.

Leroy, J. L. M. R., T. Vanholder, B. Mateusen, A. Christophe, G. Opsomer, A. de Kruif, G. Genicot, and A. Van Soom. 2005. Nonesterified fatty acids in follicular fluid of dairy cows and their effect on developmental capacity of bovine oocytes in vitro. Reproduction 130:485-495.

Lowman, B. G., N. Scott, and S. Somerville. 1976. Condition Scoring of Cattle. Rev. ed. Bull. No. 6, East of Scotland Coll. Agric., Edinburgh, UK.

McNamara, S. 2002. Effect of nutrition in the transition and early post partum period on some aspects of production and reproduction in dairy cows. PhD Diss., Natl. Univ. Ireland, Dublin.
Morton, J. M. 2001. High genetic merit and high-producing dairy cows in commercial Australian herds don't have substantially worse reproductive performance. Br. Soc. Anim. Sci. 26:305-311.

Nagelkerke, N. J. D. 1991. A note on a general definition of the coefficient of determination. Biometrika 78:691-692.

O'Mara, F. P., P. J. Caffrey, and M. J. Drennan. 1997. The net energy value of grass silage determined from comparative feeding trials. Irish J. Agric. Food Res. 36:110. (Abstr.)

Patton, J., D. A. Kenny, J. F. Mee, F. P. O’Mara, D. C. Wathes, M. Cook, and J. J. Murphy. 2006. Effect of milking frequency and diet on milk production, energy balance and reproduction in dairy cows. J. Dairy Sci. 89:1478-1487.

Pryce, J. E., M. P. Coffey, and G. Simm. 2001. The relationship between body condition score and reproductive performance. J. Dairy Sci. 84:1508-1515.

Pryce, J. E., M. D. Royal, P. C. Garnsworthy, and I. L. Mao. 2004. Fertility in the high-producing dairy cow. Livest. Prod. Sci. 86:125-135

Rabiee, A. R., I. J. Lean, J. M. Gooden, and B. G. Miller. 1999. Relationships among metabolites influencing ovarian function in the dairy cow. J. Dairy Sci. 82:39-44.

Reist, M., D. Erdin, D. von Euw, K. Tschuenperlin, H. Leuenberger, Y. Chilliard, M. Hammond, C. Morel, C. Philipona, Y. Zbinden, N. Kuenzi, and J. W. Blum. 2002. Estimation of energy balance at the individual and herd level using blood and milk traits in highyielding cows. J. Dairy Sci. 85:3314-3327.

Royal, M. D., A. O. Darwash, A. P. F. Flint, R. Webb, J. A. Woolliams, and G. E. Lamming. 2000. Declining fertility in dairy cattle: Changes in traditional and endocrine parameters of fertility. Anim. Sci. 70:487-502.

SAS Institute. 1991. User's Guide: Statistics. Version 8.1. SAS Institute, Cary, NC.

Sauer, M. J., J. A. Foulkes, A. Worsfold, and B. A. Morris. 1986. Use of progesterone 11-glucuronide-alkine phosphatase conjugate in a sensitive microtitre-plate enzyme immunoassay of progesterone in milk and its application to pregnancy testing in dairy cattle. J. Reprod. Fertil. 76:375-391.

Snijders, S. E. M., P. Dillon, D. O'Callaghan, and M. P. Boland. 1999 Effect of genetic merit, milk yield, body condition score and lactation number on in vitro oocyte development in dairy cows. Theriogenology 53:984-989.

Spicer, L. J., E. Alpizar, and S. E. Ecternkamp. 1993. Effects of insulin, insulin-like growth factor 1 , and gonadotropins on bovine granulosa cell proliferation, progesterone production, estradiol production, and (or) insulin-like growth factor 1 production in vitro. J. Anim. Sci. 71:1232-1241.

Tilley, J. M. A., and R. A. Terry. 1963. A two-stage technique for the in vitro digestion of forage crops. J. Br. Grassl. Soc. 18:104-111.

Veerkamp, R. F. 1998. Selection for economic efficiency of dairy cattle using information on live weight and feed intake: A review. J. Dairy Sci. 81:1109-1119.

Vermorel, M. 1989. Energy: The feed unit system. Pages 23-32 in Ruminant Nutrition-Recommended Allowances and Feed Tables. R. Jarrige, ed. John Libbey Eurotext, Paris, France.

Villa-Godoy, A., T. L. Hughes, R. S. Emery, L. T. Chapin, and R. L. Fogwell. 1988. Association between energy balance and luteal function in lactating dairy cows. J. Dairy Sci. 71:1063-1072.

Zulu, V. C., N. Toshihiko, and Y. Sawamukai. 2002. Insulin-like growth factor 1 as a possible hormonal mediator of nutritional regulation of reproduction in cattle. J. Vet. Med. Sci. 64:657-664. 